Check for updates

Cite this: RSC Adv., 2017, 7, 34994

Received 14th June 2017

Accepted 5th July 2017

DOI: $10.1039 / \mathrm{c} 7 \mathrm{ra06662g}$

rsc.li/rsc-advances

\section{Immobilized boronic acid for Suzuki-Miyaura coupling: application to the generation of pharmacologically relevant molecules $\uparrow$}

\author{
M. Martinez-Amezaga, C. M. L. Delpiccolo and E. G. Mata (D)* \\ An synthetic strategy for the generation of a variety of biaryl and related derivatives, based on Suzuki- \\ Miyaura coupling using immobilized boronic acid, is described. The importance of the methodology was \\ demonstrated by its further application to biologically interesting compounds such as 4-biaryl- $\beta$ - \\ lactams, descripted as cholesterol absorption inhibitors and anti-MRSA active agents, neoflavonoids, \\ imidazoles, isoxazolines, among others.
}

\section{Introduction}

Small organic molecules are of particular interest for medicinal chemistry and drug discovery not only because they constitute most of the medicines marketed today, but also because they are useful as probes to dissect biological systems providing information which eventually leads to the discovery of new drug targets. ${ }^{1}$ Through recent decades, solid-phase organic synthesis (SPOS) has become an important tool for the generation of structurally diverse small organic molecules including application to a series of very creative strategies such as diversityoriented synthesis (DOS). ${ }^{2}$ Apart from the well-known advantages, like the fast isolation of resin-bound intermediates/ products by filtering the resin beads, the use of high-boiling solvents and the easy manipulation, ${ }^{3}$ solid-phase organic synthesis has raised interest in metal-catalyzed cross-coupling reactions since undesirable soluble homodimers can be removed by filtration providing chemoselectivity, while anchoring one of the substrates makes its homodimerization a discouraging process due to the site isolation. ${ }^{4}$ An extra benefit can be considered within the principles of green chemistry: SPOS significantly reduces solvent waste by avoiding many chromatographic purifications (Scheme 1). ${ }^{5}$

The Suzuki-Miyaura coupling is, arguably, one of the most versatile and successful synthetic tool for formation of carboncarbon bonds. The Suzuki-Miyaura reaction is basically the reaction of arylboronic acids with aryl halides or pseudo halides under palladium catalyst to obtain biaryl fragments, which are present in many biologically relevant molecules. The mild reaction conditions and the broad functional groups tolerance

Instituto de Quimica Rosario (CONICET-UNR), Facultad de Ciencias Bioquímicas y Farmacéuticas, Universidad Nacional de Rosario, Suipacha 531, 2000 Rosario, Argentina. E-mail: mata@iquir-conicet.gov.ar; Fax: +54 3414370477

$\dagger$ Electronic supplementary information (ESI) available: Experimental details, spectroscopic data: ${ }^{1} \mathrm{H}$ NMR and ${ }^{13} \mathrm{C}$ NMR spectra. See DOI: 10.1039/c7ra06662g
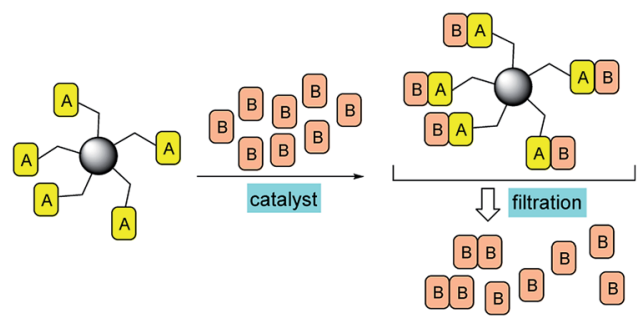

Scheme 1 Cross-coupling reaction on solid-phase synthesis.

are among the most remarkable features of this transformation, together with the fact that the non-toxic organoboron reagents can be easily synthesized by different procedures and exhibit high stability to air and moisture. ${ }^{6}$ One of the main drawbacks of Suzuki-Miyaura cross-coupling reaction is the formation of undesirable boronic acid homocoupling by-products. ${ }^{7}$ This problem can be avoided by a rigorous exclusion of oxygen giving, however, less support to the claim that Suzuki-Miyaura coupling is an "easy to handle" reaction. Site segregation in the solid-supported version of this reaction, makes self-coupling between immobilized boronic acid moieties a less favorable process. Many examples of this transformation on solid phase have been reported in the literature, ${ }^{8}$ however, very few are based on immobilized boronic acids. ${ }^{9}$

\section{Results and discussion}

For some years, our research group has been focused on the mentioned advantage of the combination of solid-phase synthesis and metal-catalyzed chemistry to build libraries of pharmacologically relevant molecules. ${ }^{10}$ In the search for alternative source of immobilized biaryl-containing $\beta$-lactam derivatives we decided to study the underdeveloped but promising solid-phase Suzuki-Miyaura reaction with a boronic acid 
Table 1 Optimization of conditions for the solid-phase version of Suzuki-Miyaura coupling with immobilized boronic acids

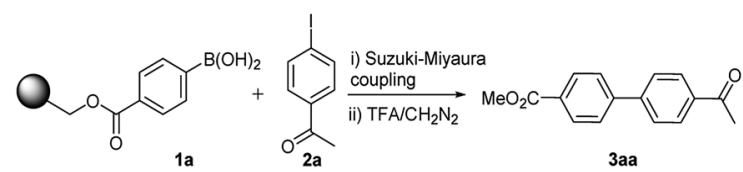

\begin{tabular}{|c|c|c|c|c|c|c|}
\hline Entry & Equiv. of iodide $\mathbf{2 a}$ & Pd catalyst (mol\%) & Base (equiv.) & Solvent & Conditions $^{a}$ & Yield $^{b}(\%)$ \\
\hline 1 & 1 & $\mathrm{Pd}(\mathrm{OAc})_{2}(5)$ & $\mathrm{K}_{2} \mathrm{CO}_{3}(1.2)$ & MeCN & $75^{\circ} \mathrm{C}, 4 \mathrm{~h}$ & $30(60)$ \\
\hline 2 & 1 & $\mathrm{PdCl}_{2} \mathrm{dppf}(5)$ & $\mathrm{K}_{2} \mathrm{CO}_{3}(1.2)$ & DMF & $75^{\circ} \mathrm{C}, 4 \mathrm{~h}$ & $22(40)$ \\
\hline 4 & 1 & $\mathrm{Pd}(\mathrm{OAc})_{2}(5)$ & $\mathrm{K}_{2} \mathrm{CO}_{3}(1.2)$ & $\mathrm{MeCN}$ & $75^{\circ} \mathrm{C}, 7 \mathrm{~h}$ & \multirow{2}{*}{$32(63)$} \\
\hline 5 & 4 & $\mathrm{Pd}(\mathrm{OAc})_{2}(10)$ & $\mathrm{K}_{2} \mathrm{CO}_{3}(2.4)$ & $\mathrm{MeCN}$ & $\mathrm{MW}, 10^{\prime}, 100{ }^{\circ} \mathrm{C}$ & \\
\hline 6 & 4 & $\mathrm{Pd}(\mathrm{OAc})_{2}(10)$ & $\mathrm{K}_{2} \mathrm{CO}_{3}(2.4)$ & $\mathrm{MeCN}$ & $100^{\circ} \mathrm{C}, 5 \mathrm{~h}$ & $40(76)$ \\
\hline 9 & 4 & $\mathrm{Pd}(\mathrm{OAc})_{2}(10)$ & $\mathrm{K}_{2} \mathrm{CO}_{3} 0.5 \mathrm{M}(2.4)$ & MeCN & Reflux, $5 \mathrm{~h}^{e}$ & 88 \\
\hline
\end{tabular}

${ }^{a}$ Except noted otherwise, all reactions were carried in a sealed tube. ${ }^{b}$ Yields were determined by ${ }^{1} \mathrm{H}$ NMR using an internal standard (mesitylene). Conversion by ${ }^{1} \mathrm{H}$ NMR in brackets. ${ }^{c}$ No starting material detected by ${ }^{1} \mathrm{H}$ NMR. ${ }^{d}$ Mixture of products, mostly starting material. ${ }^{e}$ Open system, reflux conditions.

as the immobilized substrate ${ }^{9}$ and apply the metholodogy to the generation of biaryl derivatives of privileged structures such as $\beta$-lactams, neoflavonoids, imidazoles, isoxazolines, etc.

In order to find the optimal conditions, we first synthesized the immobilized 4-carboxyphenylboronic acid 1a from 4-formylphenylboronic acid by oxidation with sodium permanganate and anchoring to Wang resin by standard procedure. We then analyzed the reaction of $\mathbf{1 a}$ with 4 -iodoacetophenone (2a) (Table 1 and Fig. 1).

When the immobilized boronic acid (1a) was treated with 1 equiv. of 4-iodoacetophenone (2a), 1.2 equiv. of $\mathrm{K}_{2} \mathrm{CO}_{3}$, under "ligand-free" conditions $\left[\mathrm{Pd}(\mathrm{OAc})_{2}(5 \mathrm{~mol} \%)\right]$, in anhydrous acetonitrile for $4 \mathrm{~h}$ at $75{ }^{\circ} \mathrm{C},{ }^{9 \boldsymbol{b}}$ an incomplete conversion was observed, and the expected product 3aa was obtained in 30\% yield, after cleavage with TFA and methylation with diazomethane (entry 1). In the case of using $\mathrm{PdCl}_{2} \mathrm{dppf}^{\mathbf{1 1}}$ (5 mol\%) as catalyst, a similar result was obtained, albeit conversion and yield were lower (entry 2). Other conditions reported in literature were also attempted, thus, Wang resin-bound phenylboronic acid (1a) was treated with the iodide 2a, $\mathrm{Pd}\left(\mathrm{PPh}_{3}\right)_{4}(5 \mathrm{~mol} \%)$ and $\mathrm{Cs}_{2} \mathrm{CO}_{3}(1,2$ equiv. $)$ in diglyme at $150{ }^{\circ} \mathrm{C}$ for $3 \mathrm{~h},{ }^{12}$ giving the expected biaryl 3aa in $37 \%$ yield but no starting material was detected by ${ }^{1} \mathrm{H}$ NMR (entry 3 ). Afterwards, we used the combination of a ligandless catalyst such as $\mathrm{Pd}_{2}(\mathrm{dba})_{3}$ and a hindered phosphine ligands $\left[\mathrm{P}(o \text {-tolyl })_{3}\right]^{13}$ in order to increase Pd catalytic activity, but a small amount of the required biaryl derivative was obtained together with an intractable mixture of products. Taking as reference the conditions of entry 1 , we proceeded to increase the reaction time, but conversion and yield were hardly affected (entry 4). Although is clear that heating effects in microwave irradiation are just thermal, ${ }^{\mathbf{1 4}}$ it is still an interesting alternative as a rapid way to reach high reaction temperatures ${ }^{15}$ in order to improve yields. However, in our case, low conversion together with a mixture of unidentified compounds was obtained under microwave irradiation (entry 5). Going back to conventional heating, we increased the equivalents of the iodide, reagents and temperature, having a slightly better yield (40\%, entry 6 ).<smiles>O=C(OCc1ccccc1)c1ccc(Br)cc1</smiles><smiles>Cc1ccc(C(N)=O)cc1</smiles><smiles>CCNc1ccc(I)cc1</smiles><smiles>Ic1cccs1</smiles>

$\mathbf{2 k}$

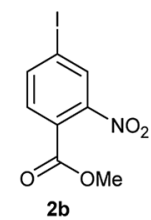<smiles>O=C1[C@H](O)[C@H](c2ccc(I)cc2)N1Cc1ccccc1</smiles>

$2 m$<smiles>COC(=O)c1ccc(I)cc1</smiles><smiles>Ic1ccccc1</smiles><smiles>Brc1ccccc1</smiles><smiles>O=[N+]([O-])c1ccc(Br)cc1</smiles>

2d'<smiles>O=Cc1ccc(Br)cc1</smiles><smiles>Cc1ccc(N)cc1</smiles><smiles>O=C1C(N2C(=O)c3ccccc3C2=O)C(c2ccc(I)cc2)N1Cc1ccccc1</smiles>

$2 n$<smiles>COc1ccc(N2C(=O)C(c3ccccc3)C2c2ccc(I)cc2)cc1</smiles><smiles>Cc1ccc(N2C(=O)[C@@H](Oc3ccccc3)[C@H]2c2ccc(I)cc2)cc1</smiles><smiles>COc1ccc(C)cc1</smiles>

2h<smiles>O=c1cc(Br)c2ccccc2o1</smiles>

2q'

Fig. 1 Structures and numbering of building blocks. 
Table 2 Solid-phase Suzuki-Miyaura reaction between organic halides and immobilized boronic acid ${ }^{a}$

Entry Halides/pseudohalides

1
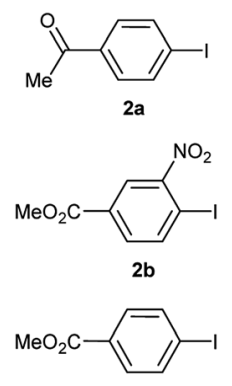

2c

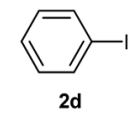

5

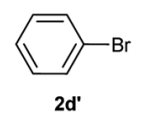

6

7

8

9

11

12

13

14

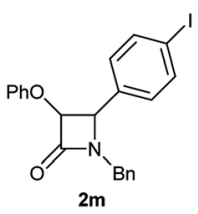

15

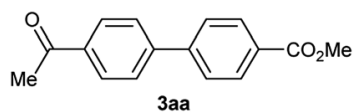

96

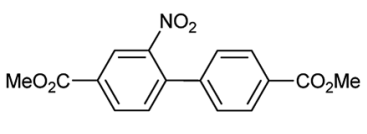

99

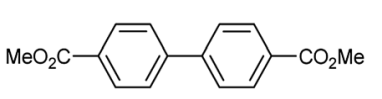

3ac

96

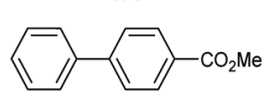

99

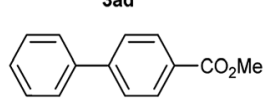

3ad

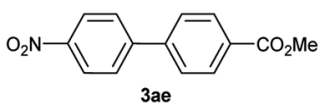

87

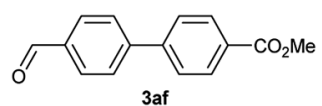

81 (78)

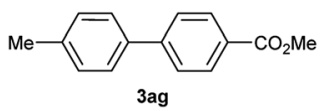

77

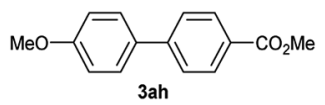

52

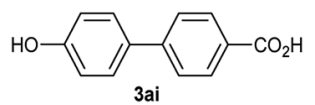

37

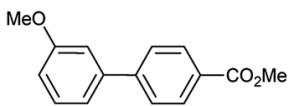

20

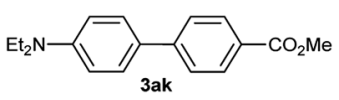

8<smiles>CC(=O)c1ccc(-c2cccs2)cc1</smiles>

15

$65(60)$ 
Table 2 (Contd.)

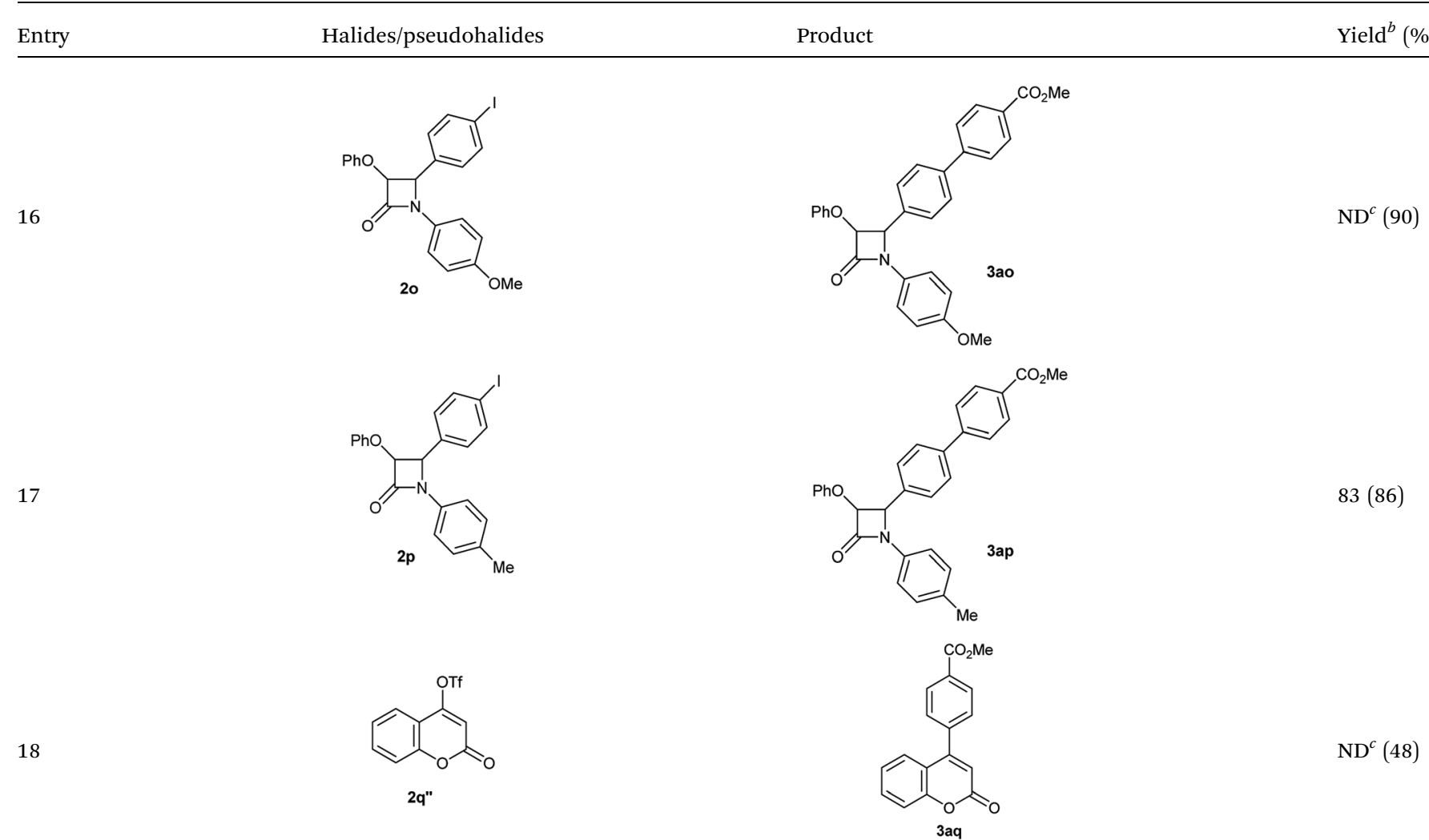

\footnotetext{
${ }^{a}$ Conditions: halide or pseudo-halide (4 equiv.), $\mathrm{Pd}(\mathrm{OAc})_{2}(10 \mathrm{~mol} \%), \mathrm{K}_{2} \mathrm{CO}_{3}$ (2.4 equiv.) in $\mathrm{H}_{2} \mathrm{O}(0.2 \mathrm{~mL}), \mathrm{MeCN}, 100{ }^{\circ} \mathrm{C}, 5 \mathrm{~h}$, in a sealed tube. ${ }^{b}$ Determined by ${ }^{1} \mathrm{H}$ NMR $v s$. internal standard (mesitylene), isolated yields after column chromatography are reported in brackets. ${ }^{c}$ ND $=$ not determined.
}

Finally, in our initial attempts we have noticed the difficulty of solubilising the carbonate and, since the addition of a base is considered to be crucial for the success of the reaction, ${ }^{16}$ we decided to study the addition of an small amount of water to increase dissolution, hoping that would not affect in any significant way the polymer support swelling. Thus, we dissolved the $\mathrm{K}_{2} \mathrm{CO}_{3}$ (2.4 equiv.) in a small amount of water and added to the suspension of resin 1a, 4-iodoacetophenone (2a) (4 equiv.) and $10 \mathrm{~mol} \%$ of $\mathrm{Pd}(\mathrm{OAc})_{2}$ in acetonitrile. To our delight, after $5 \mathrm{~h}$ at $100^{\circ} \mathrm{C}$ in a sealed tube, followed by cleaving from the resin and methylation with diazomethane, the expected product was achieved in $96 \%$ yield (entry 7 ). At the same time, a variation using more harsh conditions such as heating in diglyme at $150{ }^{\circ} \mathrm{C}$ for $5 \mathrm{~h}$, was analyzed giving lower yield, probably due to starting material/product decomposition (entry 8). Good results were obtained using an open system (entry 9), although yield of entry 7 was still the optimum.

Subsequently, the reaction of a variety of aryl halides and pseudohalides under the optimized coupling conditions was examined (Table 2 and Fig. 1). Generally speaking, yields are very high for electron-withdrawing aryl halides and nonsubstituted aryl halides (entries 1-7), independently of using an iodide or a bromide derivative. In the case of electron- donating substituents on the aryl halides, Suzuki coupling proved to be less efficient, again with little influence from the halide used (entries 8-12). As expected, 2-iodothiophene gave the corresponding heterobiaryl derivative in low yield probably due to the poisoning of the catalyst (entry 13). ${ }^{17}$ In order to apply the methodology to structures of greater complexity and interest, biaryl-containing $\beta$-lactam derivatives were synthesized using the optimized conditions. $\beta$-Lactam unit is a wellknown privileged structure present in numerous bioactive compounds. Aside from their antibacterial properties, ${ }^{18} \beta$-lactams also show other biological activities, most significantly inhibition of cholesterol absorption, that include the commercial drug ezetimibe, ${ }^{19}$ which is one of the most prescribed medicine in US.

Particularly, 4-biaryl- $\beta$-lactams have been reported as cholesterol absorption inhibitors ${ }^{20}$ and antibacterial activity against methicillin-resistant Staphylococcus aureus (MRSA). ${ }^{21}$ Thus, biaryl- $\beta$-lactams (3am-ap) were obtained in very high isolated yield (entries 14 to 17, Table 2). Another synthetic objective of great interest in medicinal chemistry are the coumarin derivatives which are well known for their diverse pharmacological properties. ${ }^{22}$ Neoflavonoids (4-arylcoumarins) in particular, have shown relevant anticancer activity, ${ }^{23}$ while 


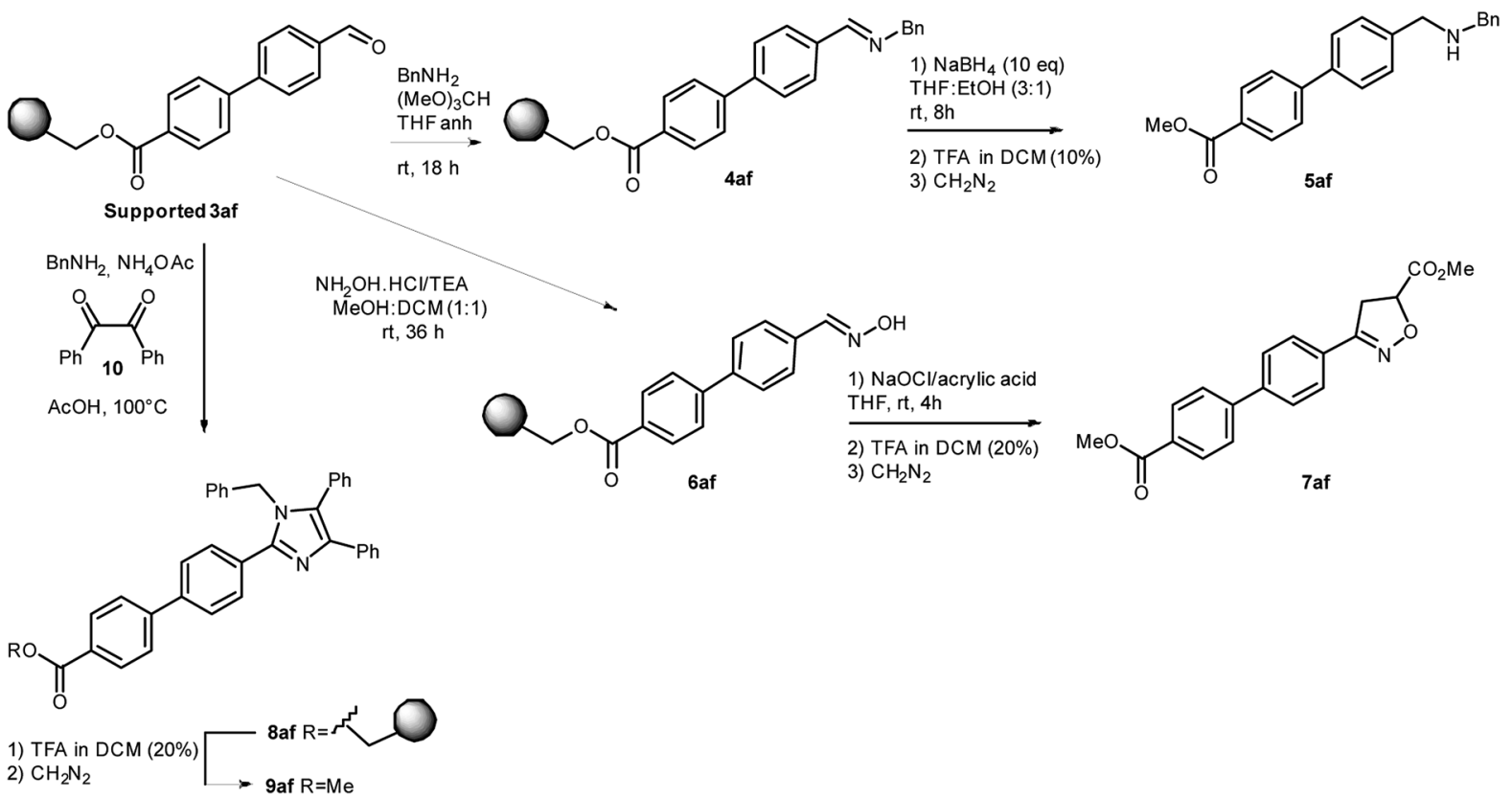

Scheme 2 Further transformation of supported aldehyde 3af to biologically interesting heterocycles.

this moiety is found in a variety of plants belonging to the families Guttiferae, Rubiaceae, Leguminosae, Passifloraceae and Compositae. ${ }^{24}$ In this case, the triflate derivative of 4-hydroxycoumarin $\left(\mathbf{2} \mathbf{q}^{\prime \prime}\right)^{25}$ was subjected to the optimized conditions in the presence of the immobilized boronic acid (1a), to give $48 \%$ isolated yield of the expected 4-arylcoumarin (3aq) (entry 18).

Solid-phase chemistry is an appreciated tool for the development of many alternative synthetic route to diverse structures. Biaryl derivatives, like the ones we have synthesized, can be interesting precursors in that sense. Thus, the immobilized version of aldehyde 3af (supported 3af) was used as a versatile intermediate for the generation of other biologically promising compounds. For instance, we carried out the synthesis of secondary amines such as the $N$-benzyl-1-(biphenyl-4-yl) methanamine derivative (5af) by a straightforward two step reductive amination (Scheme 2). The imine formation was performed by treating supported 3af with benzylamine in the presence of trimethyl orthoformate as dehydrating agent. Reduction of the imine 4af with sodium borohydride gave the corresponding secondary $N$-benzyl amine $\mathbf{5 a f}$ in a very good overall isolated yield of $60 \%$, based on loading level of resin 1a. Supported 3af was also the starting point for the synthesis of biologically interesting heterocycles such as isoxazolines and imidazoles. Thus, this compound was first treated with hydroxylamine/triethylamine ${ }^{26}$ to generate the Wang resin-bound oxime 6af (Scheme 2). A one-pot oxidation/1,3-dipolar cycloaddition was then performed using solution of sodium hypochlorite and acrylic acid as dipolarophile. ${ }^{27}$ The biphenyl-isoxazoline 7 af was obtained in a regioselective manner after removing from the resin with TFA followed by methylation $(21 \%$ overall isolated yield, always based on loading level of resin 1a). Isoxazolines are a well-known privileged structure and the corresponding 3,5disubstituted derivatives have been lately described as anti- inflamatory, ${ }^{28}$ antibacterial/antifungal agents, ${ }^{29,30}$ CFTR activators, ${ }^{31}$ and, particularly, the (S,R)-3-(4-hydroxyphenyl)-4,5dihydro-5-isoxazole acetic acid methyl ester (ISO-1) has been reported as a potent inhibitor of MIF tautomerase activity. ${ }^{32}$

Alternatively, biologically promising imidazole ${ }^{33}$ can be readily obtained by the four-component condensation of aldehydes, 1,2-diketones, amines and ammonium acetate in refluxing acetic acid as ammonia source. As an example, supported 3af was treated with excess of benzil (10) and benzylamine, in the presence of $\mathrm{NH}_{4} \mathrm{OAc}$ in acetic acid at reflux to give the supported product 8af that afforded the 1-benzyl-2-substituted-4,5-diphenyl$1 \mathrm{H}$-imidazole derivative 9af after removing from the resin and methylation ( $20 \%$ overall isolated yield). ${ }^{34}$

In summary, we report herein an efficient application of the Suzuki-Miyaura coupling to the solid-phase synthesis of a variety of biaryl and related derivatives using the underrecognized but promising alternative based on immobilized boronic acid. Yields were very high for electron-withdrawing or unsubstituted aryl halides regardless of the halide used. We have demonstrated that biologically relevant structures, including heterocycles such as 4-biaryl- $\beta$-lactams, 4 -arylcoumarins, imidazoles and isoxazolines, can be easily generated by this methodology. Biological evaluation of the synthesized compounds are currently in progress.

\section{Experimental procedures}

\section{General}

Chemical reagents were purchased from commercial sources and were used without further purification unless noted otherwise. Solvents were analytical grade or were purified by standard procedures prior to use. Resins were purchased from Sigma-Aldrich. ${ }^{1} \mathrm{H}$ NMR spectra were recorded in a Bruker 
Avance spectrometer at $300 \mathrm{MHz}$ in $\mathrm{CDCl}_{3}$ with tetramethylsilane (TMS) as internal standard. ${ }^{13} \mathrm{C}$ NMR spectra were recorded on the same apparatus at $75 \mathrm{MHz}$ with $\mathrm{CDCl}_{3}$ as solvent and reference $(76.9 \mathrm{ppm})$. The chemical shifts $(\delta)$ are reported in ppm downfield from TMS and coupling constants $(J)$ are expressed in hertz. Gas Chromatography-Mass Spectra (GC-MS) were recorded on a Shimadzu QP2010 Plus apparatus at an ionization voltage of $70 \mathrm{eV}$ equipped with a SPB ${ }^{\mathrm{TM}}-1$ capillary column (internal diameter $0.25 \mathrm{~mm}$, length $30 \mathrm{~m}$ ). The High Resolution Mass Spectra (HRMS) were obtained with a Bruker MicroTOF-Q II instrument (Bruker Daltonics, Billerica, MA). Detection of the ions was performed in electrospray ionization, positive ion mode. Solvents were dried using a MBraun solvent system (SPS-800). Analytical thin-layer chromatography (TLC) was carried out with silica gel 60 F254 pre-coated aluminum sheets. Flash column chromatography was performed using Merck silica gel 60 (230-400 mesh). Elution was carried out with hexane-EtOAc mixtures, under positive pressure and employing gradient of solvent polarity techniques.

Solid-phase reactions were carried out in polypropylene cartridges equipped with a frit (Supelco, Bellefonte, PA), unless reflux conditions were required, in that cases standard glassware was used. All solid-phase reaction mixtures were stirred at the slowest rate.

Except 2m, 2n, 2o, 2p, 3ak, 3am, 3an, 3ao and 3ap which are new compound and thoroughly characterized by ${ }^{1} \mathrm{H}$ NMR, ${ }^{13} \mathrm{C}$ NMR, HSQC, HMBC, HH-COSY and HRMS, the other compounds obtained have been previously described in literature: 3aa, ${ }^{35} 3 \mathrm{ab},{ }^{36} \mathrm{aac}^{37} \mathrm{3ad}^{36}{ }^{3 \mathrm{ae}},{ }^{35} \mathrm{aff}^{38} \mathrm{3ag}^{39}{ }^{3 \mathrm{ah}},{ }^{36} \mathrm{aai}^{40}$ $3 \mathbf{a j}^{10 f}{ }^{13} \mathbf{a l}^{36}$ and 3aq. ${ }^{41}$

\section{General procedure for the preparation of $\beta$-lactams as starting} materials (procedure $\mathrm{A}$ ) ${ }^{42}$

A mixture of 4-iodobenzaldehyde (290 mg, $1.25 \mathrm{mmol}$ ), few grains of molecular sieves $(4 \AA)$ and the corresponding amine $(1$ $\mathrm{mmol})$ in dichloromethane $(5 \mathrm{~mL})$ was stirred at $0{ }^{\circ} \mathrm{C}$ under nitrogen atmosphere for $1 \mathrm{~h}$. The solution was filtered, the solvent evaporated and the residue analyzed by ${ }^{1} \mathrm{H}$ NMR to ensure complete consumption of the amine. The crude thus obtained was dissolved in dry dichloromethane $(3 \mathrm{~mL})$ and cooled to $0{ }^{\circ} \mathrm{C}$ under nitrogen atmosphere. To the resulting solution were successively added triethylamine $(0.5 \mathrm{~mL}, 3.5$ mmol) and, dropwise, the corresponding acyl chloride (1.5 $\mathrm{mmol})$. The resulting mixture was stirred overnight at room temperature and then was washed with water $(3 \times 5 \mathrm{~mL}), 0.1 \mathrm{~N}$ $\mathrm{HCl}(3 \times 5 \mathrm{~mL})$ and a saturated solution of $\mathrm{NaHCO}_{3}(5 \mathrm{~mL})$. The organic layer was dried over $\mathrm{MgSO}_{4}$ and filtered; the solvent was evaporated under reduced pressure to give the corresponding crude $\beta$-lactam, which was further purified by column chromatography (hexane/EtOAc).

\section{Procedure for the preparation of phthalylglycyl chloride (procedure B) $)^{43}$}

Oxalyl chloride (386 $\mu \mathrm{L}, 4.5 \mathrm{mmol})$ was added to a solution of anhydrous $N$-phthaloylglycine $(615 \mathrm{mg}, 3 \mathrm{mmol})$ in toluene (8 $\mathrm{mL}$ ) and the reaction mixture was stirred at $60{ }^{\circ} \mathrm{C}$ for $3 \mathrm{~h}$. The excess of solvent and oxalyl chloride were removed by evaporation under reduced pressure and that crude was immediately used for the formation of the corresponding $\beta$-lactam.

1-Benzyl-4-(4-iodophenyl)-3-phenoxyazetidin-2-one (2m). Obtained following the general procedure A, starting from 4iodobenzaldehyde (290 mg, $1.25 \mathrm{mmol}$ ) and benzylamine (109 $\mu \mathrm{L}, 1 \mathrm{mmol})$. Then, phenoxyacetyl chloride $(207 \mu \mathrm{L}, 1.5 \mathrm{mmol})$ was added dropwise. Column chromatography (86/14-hexane/ EtOAc) provided the desired compound in $80 \%$ yield as yellow solid.

Characterization of $2 \mathrm{~m} .{ }^{1} \mathrm{H}$ NMR $\left(\mathrm{CDCl}_{3}, 300 \mathrm{MHz}\right) \delta(\mathrm{ppm})$ : 3.87 (d, $J=14.7 \mathrm{~Hz}, 2 \mathrm{H}), 4.68$ (d, $J=4.5 \mathrm{~Hz}, 2 \mathrm{H}), 4.87$ (d, $J=$ $14.7 \mathrm{~Hz}, 2 \mathrm{H}), 5.39$ (d, $J=4.5 \mathrm{~Hz}, 2 \mathrm{H}), 6.72(\mathrm{~d}, J=7.8 \mathrm{~Hz}, 2 \mathrm{H})$, $6.89(\mathrm{t}, J=7.1 \mathrm{~Hz}, 1 \mathrm{H}), 7.01(\mathrm{~d}, J=8.3 \mathrm{~Hz}, 2 \mathrm{H}), 7.10-7.16(\mathrm{~m}$, $4 \mathrm{H}), 7.29-7.33(\mathrm{~m}, 3 \mathrm{H}), 7.61(\mathrm{~d}, J=8.3 \mathrm{~Hz}, 2 \mathrm{H}) .{ }^{13} \mathrm{C} \mathrm{NMR}\left(\mathrm{CDCl}_{3}\right.$, $75 \mathrm{MHz}) \delta$ (ppm): 44.3, 60.9, 82.0, 94.7, 115.5, 122.2, 128.1, $128.7,128.9$, 129.3, 130.5, 132.7, 134.5, 137.5, 156.8, 165.4. HRMS (ESI) $m / z 478.0279\left[\left(\mathrm{M}+\mathrm{Na}^{+}\right)\right.$; calcd for $\mathrm{C}_{22} \mathrm{H}_{18} \mathrm{INNaO}_{2}$ : 478.0274].

2-(1-Benzyl-2-(4-iodophenyl)-4-oxoazetidin-3-yl)isoindoline1,3-dione (2n). Obtained following the general procedures A, starting from 4-iodobenzaldehyde (298 $\mathrm{mg}, 1.3 \mathrm{mmol}$ ) and benzylamine (115 $\mu \mathrm{L}, 1.05 \mathrm{mmol})$. Then, phthalylglycyl chloride prepared in situ (procedure B) (350 mg, $1.56 \mathrm{mmol}$ ). Column chromatography (75/25-hexane/EtOAc) provided the desired compound in $41 \%$ yield as colorless glass-like solid.

Characterization of $2 \mathrm{n} .{ }^{1} \mathrm{H}$ NMR: $\left(\mathrm{CDCl}_{3}, 300 \mathrm{MHz}\right) \delta(\mathrm{ppm})$ : $4.15(\mathrm{~d}, J=14.8 \mathrm{~Hz}, 1 \mathrm{H}), 4.76(\mathrm{~d}, J=5.3 \mathrm{~Hz}, 1 \mathrm{H}), 5.03(\mathrm{~d}, J=$ $14.9 \mathrm{~Hz}, 1 \mathrm{H}), 5.23(\mathrm{~d}, J=5.2 \mathrm{~Hz}, 1 \mathrm{H}), 6.95(\mathrm{~d}, J=8.2 \mathrm{~Hz}, 2 \mathrm{H})$, $7.20-7.25$ (m, 2H), 7.30-7.34 (m, 3H), 7.51 (d, $J=8.3 \mathrm{~Hz}, 2 \mathrm{H})$, 7.62-7.70 (m, 4H). ${ }^{13} \mathrm{C}$ NMR: $\left(\mathrm{CDCl}_{3}, 75 \mathrm{MHz}\right) \delta(\mathrm{ppm}): 45.6$, 59.7, 60.2 , 94.3, 123.6, 128.1, 128.6, 129.0, 129.3, 131.1, 132.8, 134.4, 137.6, 163.6, 166.7. HRMS (ESI) $m / z 531.0177\left[\left(\mathrm{M}+\mathrm{Na}^{+}\right)\right.$; calcd for $\left.\mathrm{C}_{24} \mathrm{H}_{17} \mathrm{IN}_{2} \mathrm{NaO}_{3}: 531.0176\right]$.

4-(4-iodophenyl)-1-(4-methoxyphenyl)-3-phenoxyazetidin-2one (2o). Obtained following the general procedure A, starting from 4-iodobenzaldehyde (298 $\mathrm{mg}, 1.3 \mathrm{mmol}$ ) and $p$-anisidine (160 mg, $1.05 \mathrm{mmol})$. Then, phenoxyacetyl chloride $(215 \mu \mathrm{L}$, $1.56 \mathrm{mmol})$ was added dropwise. Column chromatography (88/ 12-hexane/EtOAc) provided the desired compound in $70 \%$ yield as yellow solid.

Characterization of $20 .{ }^{1} \mathrm{H}$ NMR: $\left(\mathrm{CDCl}_{3}, 300 \mathrm{MHz}\right) \delta(\mathrm{ppm})$ : $3.76(\mathrm{~s}, 3 \mathrm{H}), 5.31$ (d, $J=4.9 \mathrm{~Hz}, 1 \mathrm{H}), 5.55(\mathrm{~d}, J=4.9 \mathrm{~Hz}, 1 \mathrm{H})$, 6.78-6.83 (m, 4H), 6.92-7.00 (m, 2H), $7.11(\mathrm{~d}, J=8.3 \mathrm{~Hz}, 2 \mathrm{H})$, $7.11(\mathrm{t}, J=7.6 \mathrm{~Hz}, 1 \mathrm{H}), 7.27(\mathrm{~d}, J=7.1 \mathrm{~Hz}, 2 \mathrm{H}), 7.62(\mathrm{~d}, J=$ $8.3 \mathrm{~Hz}, 2 \mathrm{H}) .{ }^{13} \mathrm{C} \mathrm{NMR}:\left(\mathrm{CDCl}_{3}, 75 \mathrm{MHz}\right) \delta$ (ppm): 55.5, 61.7, 81.2, 94.6, 114.5, 115.7, 118.8, 122.4, 129.4, 129.6, 130.1, 132.7, 137.6, 156.7, 156.9, 162.3. HRMS (ESI) $m / z 494.0226\left[\left(\mathrm{M}+\mathrm{Na}^{+}\right)\right.$; calcd for $\mathrm{C}_{22} \mathrm{H}_{18} \mathrm{INNaO}_{3}$ : 494.0224].

4-(4-iodophenyl)-3-phenoxy-1-(p-tolyl)azetidin-2-one (2p). Obtained following the general procedure A, starting from 4iodobenzaldehyde (298 mg, $1.3 \mathrm{mmol}$ ) and $p$-toluidine (140 mg, $1.05 \mathrm{mmol})$. Then, phenoxyacetyl chloride $(215 \mu \mathrm{L}, 1.56 \mathrm{mmol})$ was added dropwise. Column chromatography (90/10-hexane/ EtOAc) provided the desired compound in $40 \%$ yield as yellow solid. 
Characterization of $2 p .{ }^{1} \mathrm{H}$ NMR: $\left(\mathrm{CDCl}_{3}, 300 \mathrm{MHz}\right) \delta(\mathrm{ppm})$ : $2.29(\mathrm{~s}, 3 \mathrm{H}), 5.32(\mathrm{~d}, J=4.9 \mathrm{~Hz}, 1 \mathrm{H}), 5.55(\mathrm{~d}, J=4.9 \mathrm{~Hz}, 1 \mathrm{H}), 6.79$ $(\mathrm{d}, J=8.3 \mathrm{~Hz}, 2 \mathrm{H}), 6.94(\mathrm{t}, J=7.4 \mathrm{~Hz}, 1 \mathrm{H}), 7.07-7.12(\mathrm{~m}, 4 \mathrm{H})$, 7.16-7.24 (m, 4H), 7.62 (d, $J=8.3 \mathrm{~Hz}, 2 \mathrm{H}) .{ }^{13} \mathrm{C} \mathrm{NMR:}\left(\mathrm{CDCl}_{3}, 75\right.$ MHz) $\delta$ (ppm): 20.9, 61.5, 81.1, 94.6, 115.9, 117.4, 122.4, 129.4, 129.8, 129.9, 132.6, 134.2, 134.6, 137.6, 156.9, 162.6. HRMS (ESI) $m / z 478.0268\left[\left(\mathrm{M}+\mathrm{Na}^{+}\right)\right.$; calcd for $\mathrm{C}_{22} \mathrm{H}_{18} \mathrm{INNaO}_{2}$ : 478.0274].

\section{Procedure for the synthesis of Wang resin-supported aryl boronic acid 1a (procedure $\mathrm{C}$ )}

$0.4 \mathrm{~g}$ of Wang resin $\left(0.9 \mathrm{mmol} \mathrm{g}^{-1}, 0.36 \mathrm{mmol}\right)$ was swelled by gentle stirring in anhydrous dichloromethane $(20 \mathrm{~mL})$. Then, 4carboxyphenylboronic acid $(0.179 \mathrm{~g}, 1.08 \mathrm{mmol})$, DCC $\left(N, N^{\prime}-\right.$ diisopropylcarbodiimide) $(0.223 \mathrm{~g}, 1.08 \mathrm{mmol})$ and DMAP (catalytic amount) were added at that suspension. The mixture was shaked at $250 \mathrm{rpm}$ overnight at room temperature. After filtration, the resin was sequentially washed with $\mathrm{CH}_{2} \mathrm{Cl}_{2}(3 \times$ $10 \mathrm{~mL}), \mathrm{MeOH}(3 \times 10 \mathrm{~mL}), \mathrm{THF}(3 \times 10 \mathrm{~mL}), \mathrm{CH}_{2} \mathrm{Cl}_{2}(1 \times 10$ $\mathrm{mL}$ ) and finally dried under high vacuum. Mass recovery was used to determine resin loading after cleavage of an aliquot with $10 \% \mathrm{TFA} / \mathrm{CH}_{2} \mathrm{Cl}_{2}: 0.45 \mathrm{mmol} \mathrm{g}^{-1}$.

\section{General procedure for the solid-phase Suzuki coupling (procedure D)}

$0.1 \mathrm{~g}$ of the supported arylboronic acid $1 \mathrm{a}\left(0.45 \mathrm{mmol} \mathrm{g}^{-1}, 0.045\right.$ $\mathrm{mmol}$ ) was suspended in MeCN (2 mL) in a dram vessel. Arylhalide or pseudo-halide $2(0.18 \mathrm{mmol}), \mathrm{Pd}(\mathrm{OAc})_{2}(1 \mathrm{mg}, 0.0045$ $\mathrm{mmol})$ and a solution of $\mathrm{K}_{2} \mathrm{CO}_{3}$ in $\mathrm{H}_{2} \mathrm{O}(0.54 \mathrm{M}, 0.108 \mathrm{mmol})$ were added. The reaction was stirred $5 \mathrm{~h}$ at $100{ }^{\circ} \mathrm{C}$. After cooling to room temperature, the resin was filtered, washed with $\mathrm{MeCN}(2 \times$ $5 \mathrm{~mL}), \mathrm{H}_{2} \mathrm{O}(2 \times 5 \mathrm{~mL}), \mathrm{MeOH}(3 \times 5 \mathrm{~mL})$ and DCM $(3 \times 5 \mathrm{~mL})$ drying under high vacuum, the compound was cleaved from the resin with $5 \mathrm{~mL}$ of a $10 \%$ solution of TFA in DCM for 50 minutes at room temperature. Then it was filtered and washed with $\mathrm{MeOH}$ $(2 \times 3 \mathrm{~mL})$ and $\mathrm{CH}_{2} \mathrm{Cl}_{2}(2 \times 3 \mathrm{~mL})$. The product-containing solution was concentrated under reduced pressure and dried under high vacuum. Esterification with diazomethane afforded the crude product that was analyzed by ${ }^{1} \mathrm{H}$ NMR and GC/MS and then purified by flash column chromatography (hexane/EtOAc).

Dimethyl 2-nitro-[1,1'-biphenyl]-4,4'-dicarboxylate (3ab). Obtained following the general procedure $\mathrm{D}$, using resin-bound boronic acid 1a (procedure C) (103.5 mg, $0.0465 \mathrm{mmol}$ ) as starting material and methyl 4-iodo-3-nitrobenzoate (2b) (57 mg, $0.186 \mathrm{mmol}$ ). Column chromatography (96/4-hexane/ EtOAc) provided the desired compound in $92 \%$ yield as white crystals.

Characterization of $3 \boldsymbol{a b} .{ }^{1} \mathrm{H}$ NMR $\left(\mathrm{CDCl}_{3}, 300 \mathrm{MHz}\right) \delta(\mathrm{ppm})$ : $3.95(\mathrm{~s}, 3 \mathrm{H}), 4.00(\mathrm{~s}, 3 \mathrm{H}), 7.40(\mathrm{~d}, J=8.4 \mathrm{~Hz}, 2 \mathrm{H}), 7.54(\mathrm{~d}, J=$ $8.0 \mathrm{~Hz}, 1 \mathrm{H}), 8.11(\mathrm{~d}, J=8.5 \mathrm{~Hz}, 2 \mathrm{H}), 8.29(\mathrm{dd}, J=8.0,1.7 \mathrm{~Hz}$, $1 \mathrm{H}), 8.55$ (d, $J=1.7 \mathrm{~Hz}, 1 \mathrm{H}) .{ }^{13} \mathrm{C} \mathrm{NMR}\left(\mathrm{CDCl}_{3}, 75 \mathrm{MHz}\right) \delta(\mathrm{ppm})$ : 52.3, 52.9, 125.5, 127.9, 130.0, 130.5, 131.0, 132.1, 133.1, 139.5, 141.1, 148.9, 164.7, 166.5.

Dimethyl [1,1'-biphenyl]-4,4'-dicarboxylate (3ac). Obtained following the general procedure $\mathrm{D}$, using resin-bound boronic acid 1a (procedure C) (93.5 $\mathrm{mg}, 0.042 \mathrm{mmol}$ ) as starting material and methyl 4-iodobenzoate (2c) (44 mg, $0.168 \mathrm{mmol}$ ). Column chromatography (98/2-hexane/EtOAc) provided the desired compound in $89 \%$ yield as white crystals.

Characterization of 3ac. ${ }^{1} \mathrm{H} \mathrm{NMR}\left(\mathrm{CDCl}_{3}, 300 \mathrm{MHz}\right) \delta$ (ppm): $3.95(\mathrm{~s}, 6 \mathrm{H}), 7.69(\mathrm{~d}, J=8.5 \mathrm{~Hz}, 4 \mathrm{H}), 8.12(\mathrm{~d}, J=8.5 \mathrm{~Hz}, 4 \mathrm{H}) .{ }^{13} \mathrm{C}$ NMR $\left(\mathrm{CDCl}_{3}, 75 \mathrm{MHz}\right) \delta(\mathrm{ppm}): 52.2,127.2,129.7,130.2,144.3$, 166.8 .

Methyl [1,1'-biphenyl]-4-carboxylate (3ad). Obtained following the general procedure $\mathrm{D}$, using resin-bound boronic acid 1a (Procedure C) (99.6 mg, $0.0448 \mathrm{mmol}$ ) as starting material and iodobenzene $(2 \mathrm{~d})(20 \mu \mathrm{L}, 0.18 \mathrm{mmol})$. Column chromatography (99/1-hexane/EtOAc) provided the desired compound in $98 \%$ yield as white crystals.

Characterization of 3 ad. ${ }^{1} \mathrm{H}$ NMR $\left(\mathrm{CDCl}_{3}, 300 \mathrm{MHz}\right) \delta(\mathrm{ppm})$ : $3.95(\mathrm{~s}, 3 \mathrm{H}), 7.36-7.51(\mathrm{~m}, 3 \mathrm{H}), 7.60-7.70(\mathrm{~m}, 4 \mathrm{H}), 8.11(\mathrm{~d}, J=$ $8.6 \mathrm{~Hz}, 2 \mathrm{H}) .{ }^{13} \mathrm{C} \mathrm{NMR}\left(\mathrm{CDCl}_{3}, 75 \mathrm{MHz}\right) \delta(\mathrm{ppm}): 52.1,127.0$, 127.3, 128.1, 128.9, 130.1, 140.0, 145.6, 167.0.

Methyl 4'-formyl-[1,1'-biphenyl]-4-carboxylate (3af). Obtained following the general procedure $\mathrm{D}$, using resin-bound boronic acid 1a (procedure C) $(97.7 \mathrm{mg}, 0.0439 \mathrm{mmol})$ as starting material and 4-bromobenzaldehyde (2f') (32 $\mathrm{mg}, 0.175 \mathrm{mmol}$ ). Column chromatography (98/2-hexane/EtOAc) provided the desired compound in $78 \%$ yield as white crystals.

Characterization of 3af. ${ }^{1} \mathrm{H}$ NMR $\left(\mathrm{CDCl}_{3}, 300 \mathrm{MHz}\right) \delta$ (ppm): $3.95(\mathrm{~s}, 3 \mathrm{H}), 7.70(\mathrm{~d}, J=8.5 \mathrm{~Hz}, 2 \mathrm{H}), 7.78(\mathrm{~d}, J=8.3 \mathrm{~Hz}, 2 \mathrm{H}), 7.98$ (d, $J=8.3 \mathrm{~Hz}, 2 \mathrm{H}), 8.14$ (d, $J=8.5 \mathrm{~Hz}, 2 \mathrm{H}), 10.08(\mathrm{~s}, 1 \mathrm{H}) \cdot{ }^{13} \mathrm{C}$ NMR (CDCl3, $75 \mathrm{MHz}) \delta(\mathrm{ppm}): 52.3,127.4,128.0,130.3,130.3$, 144.0, 145.9, 166.7, 191.8.

Methyl 4'-(diethylamino)-[1,1'-biphenyl]-4-carboxylate (3ak). Obtained following the general procedure $\mathrm{D}$, using resin-bound boronic acid 1a (procedure C) (92.1 $\mathrm{mg}, 0.041 \mathrm{mmol}$ ) as starting material and $N, N$-diethyl-4-iodoaniline (2k) (49 mg, $0.18 \mathrm{mmol}$ ). Column chromatography (98/2-hexane/EtOAc) provided the desired compound in $9 \%$ yield as yellow fluorescent crystals.

Characterization of $3 \boldsymbol{a k} .{ }^{1} \mathrm{H} \mathrm{NMR}\left(\mathrm{CDCl}_{3}, 300 \mathrm{MHz}\right) \delta(\mathrm{ppm}): 1.20$ $(\mathrm{t}, J=7.0 \mathrm{~Hz}, 6 \mathrm{H}), 3.40(\mathrm{q}, J=7.0 \mathrm{~Hz}, 4 \mathrm{H}), 3.91(\mathrm{~s}, 3 \mathrm{H}), 6.75(\mathrm{~d}, J=$ $8.9 \mathrm{~Hz}, 2 \mathrm{H}), 7.53(\mathrm{~d}, J=8.9 \mathrm{~Hz}, 2 \mathrm{H}), 7.61(\mathrm{~d}, J=8.9 \mathrm{~Hz}, 2 \mathrm{H}), 8.04(\mathrm{~d}$, $J=8.9 \mathrm{~Hz}, 2 \mathrm{H}) .{ }^{13} \mathrm{C} \mathrm{NMR}\left(\mathrm{CDCl}_{3}, 75 \mathrm{MHz}\right) \delta(\mathrm{ppm}): 12.6,44.4,51.9$, 111.8, 125.5, 126.3, 127.1, 128.1, 130.0, 145.7, 147.8, 167.3. HRMS (ESI) $m / z 284.1656\left[\left(\mathrm{M}+\mathrm{H}^{+}\right)\right.$; calcd for $\mathrm{C}_{18} \mathrm{H}_{22} \mathrm{NO}_{2}$ : 284.1645].

Methyl 4'-(1-benzyl-4-oxo-3-phenoxyazetidin-2-yl)-[1,1'biphenyl]-4-carboxylate (3am). Obtained following the general procedure D, using resin-bound boronic acid 1a (procedure $\mathrm{C}$ ) (93.3 $\mathrm{mg}, 0.042 \mathrm{mmol}$ ) as starting material and 1-benzyl-4-(4iodophenyl)-3-phenoxyazetidin-2-one $\quad(2 \mathrm{~m}) \quad(76 \quad \mathrm{mg}, \quad 0.168$ mmol). Column chromatography (86/14-hexane/EtOAc) provided the desired compound in $76 \%$ yield as yellowish white crystals.

Characterization of $3 \mathbf{a m} .{ }^{1} \mathrm{H}$ NMR: $\left(\mathrm{CDCl}_{3}, 300 \mathrm{MHz}\right) \delta(\mathrm{ppm})$ : $3.92(\mathrm{~d}, J=14.5 \mathrm{~Hz}, 1 \mathrm{H}), 3.94(\mathrm{~s}, 3 \mathrm{H}), 4.81$ (d, $J=4.4 \mathrm{~Hz}, 1 \mathrm{H}), 4.92$ $(\mathrm{d}, J=14.7 \mathrm{~Hz}, 1 \mathrm{H}), 5.44(\mathrm{~d}, J=4.4 \mathrm{~Hz}, 1 \mathrm{H}), 6.75(\mathrm{~d}, J=7.8 \mathrm{~Hz}$, $2 \mathrm{H}), 6.87(\mathrm{t}, J=7.3 \mathrm{~Hz}, 1 \mathrm{H}), 7.11(\mathrm{t}, J=8.3 \mathrm{~Hz}, 2 \mathrm{H}), 7.18(\mathrm{~m}, 2 \mathrm{H})$, $7.33(\mathrm{~m}, 2 \mathrm{H}), 7.37$ (d, $J=8.3 \mathrm{~Hz}, 2 \mathrm{H}), 7.54(\mathrm{~d}, J=8.2 \mathrm{~Hz}, 2 \mathrm{H}), 7.62$ $(\mathrm{d}, J=8.3 \mathrm{~Hz}, 2 \mathrm{H}) .{ }^{13} \mathrm{C} \mathrm{NMR:}\left(\mathrm{CDCl}_{3}, 75 \mathrm{MHz}\right) \delta(\mathrm{ppm}): 44.3,52.2$, 61.1, 82.3, 115.6, 122.1, 127.0, 127.1, 128.0, 128.7, 128.9, 129.1, 129.2, 130.1, 132.8, 134.7, 140.2, 156.9, 165.5, 166.9. HRMS (ESI) $m / z 486.1670\left[\left(\mathrm{M}+\mathrm{Na}^{+}\right)\right.$; calcd for $\mathrm{C}_{30} \mathrm{H}_{25} \mathrm{NNaO}_{4}$ : 486.1676].

Methyl 4'-(1-benzyl-3-(1,3-dioxoisoindolin-2-yl)-4-oxoazetidin-2-yl)-[1,1'-biphenyl]-4-carboxylate (3an). Obtained following 
the general procedure $\mathrm{D}$, using resin-bound boronic acid 1a (procedure C) (90 mg, $0.0405 \mathrm{mmol}$ ) as starting material and 2(1-benzyl 2-(4-iodophenyl)-4-oxoazetidin-3-yl)isoindoline-1,3dione (2n) (82.3 mg, $0.162 \mathrm{mmol}$ ). Column chromatography (78/22-hexane/EtOAc) provided the desired compound in $60 \%$ yield as white crystals.

Characterization of 3an. ${ }^{1} \mathrm{H}$ NMR: $\left(\mathrm{CDCl}_{3}, 300 \mathrm{MHz}\right) \delta(\mathrm{ppm})$ : $3.91(\mathrm{~s}, 3 \mathrm{H}) ; 4.21$ (d, $J=14.8 \mathrm{~Hz}, 1 \mathrm{H}), 4.90(\mathrm{~d}, J=5.2 \mathrm{~Hz}, 1 \mathrm{H})$, $5.10(\mathrm{~d}, J=14.8 \mathrm{~Hz}, 1 \mathrm{H}), 5.52(\mathrm{t}, J=5.2 \mathrm{~Hz}, 1 \mathrm{H}), 7.28-7.36(\mathrm{~m}$, $7 \mathrm{H}), 7.47$ (d, $J=8.4 \mathrm{~Hz}, 2 \mathrm{H}), 7.50$ (d, $J=8.4 \mathrm{~Hz}, 2 \mathrm{H}), 7.59-7.69$ $(\mathrm{m}, 4 \mathrm{H}), 8.02(\mathrm{~d}, J=8.3 \mathrm{~Hz}, 2 \mathrm{H}) .{ }^{13} \mathrm{C} \mathrm{NMR:}\left(\mathrm{CDCl}_{3}, 75 \mathrm{MHz}\right)$ $\delta$ (ppm): 45.7, 52.1, 60.0, 60.3, 123.5, 126.8, 127.3, 128.0, 128.1, $128.7,129.0,129.1,130.0,131.2$, 133.0, 134.2, 134.8, 139.9, 144.5, 163.7, 166.8. HRMS (ESI) $m / z 539.1587$ [( $\left.\mathrm{M}+\mathrm{Na}^{+}\right)$; calcd for $\mathrm{C}_{32} \mathrm{H}_{24} \mathrm{~N}_{2} \mathrm{NaO}_{5}$ : 539.1577].

Methyl 4'-(1-(4-methoxyphenyl)-4-oxo-3-phenoxyazetidin-2yl)-[1,1'-biphenyl]-4-carboxylate (3ao). Obtained following the general procedure $\mathrm{D}$, using resin-bound boronic acid 1a (procedure C) $(89.3 \mathrm{mg}, 0.04018 \mathrm{mmol})$ as starting material and 4-(4-iodophenyl)-1-(4-methoxyphenyl)-3-phenoxyazetidin-2-one (2o) (76.3 mg, $0.162 \mathrm{mmol})$. Column chromatography (86/14hexane/EtOAc) provided the desired compound in $90 \%$ yield as yellowish white crystals.

Characterization of 3ao. ${ }^{1} \mathrm{H}$ NMR: $\left(\mathrm{CDCl}_{3}, 300 \mathrm{MHz}\right) \delta(\mathrm{ppm})$ : $3.75(\mathrm{~s}, 3 \mathrm{H}), 3.93(\mathrm{~s}, 3 \mathrm{H}), 5.41(\mathrm{~d}, J=4.8 \mathrm{~Hz}, 1 \mathrm{H}), 5.65(\mathrm{~d}, J=$ $4.8 \mathrm{~Hz}, 1 \mathrm{H}), 6.82(\mathrm{~d}, J=8.9 \mathrm{~Hz}, 2 \mathrm{H}), 6.92(\mathrm{t}, J=7.3 \mathrm{~Hz}, 1 \mathrm{H}), 7.16(\mathrm{t}$, $J=8.0 \mathrm{~Hz}, 2 \mathrm{H}), 7.33(\mathrm{~d}, J=8.9 \mathrm{~Hz}, 2 \mathrm{H}), 7.46(\mathrm{~d}, J=8.2 \mathrm{~Hz}, 2 \mathrm{H})$, $7.55(\mathrm{~d}, J=8.2 \mathrm{~Hz}, 2 \mathrm{H}), 7.60(\mathrm{~d}, J=8.3 \mathrm{~Hz}, 2 \mathrm{H}), 8.07(\mathrm{~d}, J=8.3 \mathrm{~Hz}$, 2H). ${ }^{13} \mathrm{C} \mathrm{NMR:}\left(\mathrm{CDCl}_{3}, 75 \mathrm{MHz}\right) \delta$ (ppm): 52.2, 55.5, 61.8, 81.4, 114.5, 115.8, 118.9, 122.3, 127.0, 127.2 , 128.7, 129.1, 129.3, 130.1, 130.4, 132.8, 140.3, 144.8, 156.6, 157.0, 162.4, 166.9. HRMS (ESI) $m / z 502.1634\left[\left(\mathrm{M}+\mathrm{Na}^{+}\right)\right.$; calcd for $\left.\mathrm{C}_{30} \mathrm{H}_{25} \mathrm{NNaO}_{5}: 502.1625\right]$.

Methyl 4'-(4-oxo-3-phenoxy-1-( $p$-tolyl)azetidin-2-yl)-[1,1'biphenyl]-4-carboxylate (3ap). Obtained following the general procedure D, using resin-bound boronic acid 1a (procedure $\mathrm{C}$ ) (90 mg, $0.0405 \mathrm{mmol}$ ) as starting material and 4-(4-iodophenyl)-3phenoxy-1-(p-tolyl)azetidin-2-one (2p) (73.7 mg, $0.162 \mathrm{mmol})$. Column chromatography (88/12-hexane/EtOAc) provided the desired compound in $86 \%$ yield as white crystals.

Characterization of 3ap. ${ }^{1} \mathrm{H}$ NMR: $\left(\mathrm{CDCl}_{3}, 300 \mathrm{MHz}\right) \delta(\mathrm{ppm})$ : $2.28(\mathrm{~s}, 3 \mathrm{H}) ; 3.93(\mathrm{~s}, 3 \mathrm{H}) ; 5.43(\mathrm{~d}, J=4.8 \mathrm{~Hz}, 1 \mathrm{H}), 5.60(\mathrm{~d}, J=$ $4.8 \mathrm{~Hz}, 1 \mathrm{H}), 6.82(\mathrm{~d}, J=8.0 \mathrm{~Hz}, 2 \mathrm{H}), 6.92(\mathrm{t}, J=7.4 \mathrm{~Hz}, 1 \mathrm{H}), 7.09$ $(\mathrm{d}, J=8.2 \mathrm{~Hz}, 2 \mathrm{H}), 7.17(\mathrm{t}, J=8.0 \mathrm{~Hz}, 2 \mathrm{H}), 7.29(\mathrm{~d}, J=8.3 \mathrm{~Hz}$, $2 \mathrm{H}), 7.46$ (d, $J=8.3 \mathrm{~Hz}, 2 \mathrm{H}), 7.54(\mathrm{~d}, J=8.3 \mathrm{~Hz}, 2 \mathrm{H}), 7.61$ (d, $J=$ $8.3 \mathrm{~Hz}, 2 \mathrm{H}), 8.07(\mathrm{~d}, J=8.3 \mathrm{~Hz}, 2 \mathrm{H}) .{ }^{13} \mathrm{C} \mathrm{NMR}:\left(\mathrm{CDCl}_{3}, 75 \mathrm{MHz}\right)$ $\delta$ (ppm): 21.0, 52.2, 61.7, 81.3, 115.8, 117.5, 122.3, 126.9, 127.2, $128.7,129.1,129.3,129.7,130.1,132.8,134.5,134.5,140.2$, 144.8, 157.0, 162.8, 166.9. HRMS (ESI) $m / z$ 486.1677 [( $\left.\mathrm{M}+\mathrm{Na}^{+}\right)$; calcd for $\mathrm{C}_{30} \mathrm{H}_{25} \mathrm{NNaO}_{4}$ : 486.1676].

Methyl 4-(2-oxo-2H-chromen-4-yl)benzoate (3aq). Obtained following the general procedure $\mathrm{D}$, using resin-bound boronic acid 1a (procedure C) (92.9 $\mathrm{mg}, 0.0418 \mathrm{mmol}$ ) as starting material and 4-iodo-2H-chromen-2-one (2q") (49.1 mg, 0.167 mmol). Column chromatography (90/10-hexane/EtOAc) provided the desired compound in $48 \%$ yield as white crystals.

Characterization of 3aq. ${ }^{1} \mathrm{H} \mathrm{NMR}\left(\mathrm{CDCl}_{3}, 300 \mathrm{MHz}\right) \delta(\mathrm{ppm})$ : 3.98 (s, 3H), 6.40 (s, 1H), 7.24 (m, 1H), 7.38-7.45 (m, 2H), 7.52- $7.60(\mathrm{~m}, 3 \mathrm{H}), 8.20(\mathrm{~d}, J=8.3 \mathrm{~Hz}, 2 \mathrm{H}) ;{ }^{13} \mathrm{C} \mathrm{NMR}\left(\mathrm{CDCl}_{3}, 75 \mathrm{MHz}\right)$ $\delta$ (ppm): 52.5, 115.6, 117.5, 118.6, 124.4, 126.7, 128.6, 130.1, $131.4,132.2$, 139.6, 154.2, 154.6, 160.4, 166.3.

\section{Procedure for the solid-phase reductive amination (procedure E)}

$0.3 \mathrm{~g}$ of the supported compound 3af $\left(0.438 \mathrm{mmol} \mathrm{g}^{-1}, 0.135\right.$ mmol) was suspended in anhydrous THF $(2 \mathrm{~mL})$ in a dram vessel. Benzylamine (75 $\mu \mathrm{L}, 0.673 \mathrm{mmol})$ and methyl orthoformate $(15 \mu \mathrm{L}, 0.135 \mathrm{mmol})$ were added and the reaction was stirred $18 \mathrm{~h}$ at room temperature. After that time, the imineresin was filtered, washed with $\mathrm{THF}(2 \times 5 \mathrm{~mL})$, absolute MeOH $(2 \times 5 \mathrm{~mL}), \mathrm{DCM}(2 \times 5 \mathrm{~mL})$ and $\mathrm{MeOH}(2 \times 5 \mathrm{~mL})$ and dried under high vacuum. This resin was suspended in a mixture of THF-MeOH $3: 1 \mathrm{v} / \mathrm{v}$ and treated with $\mathrm{NaBH}_{4}$ (51 mg, $1.347 \mathrm{mmol}$ ) for 6 to 8 hours. The resin was washed with THF $(2 \times 5 \mathrm{~mL})$, EtOH $(2 \times 5 \mathrm{~mL}), \mathrm{H}_{2} \mathrm{O}(2 \times 5 \mathrm{~mL})$, EtOH $(2 \times 5$ $\mathrm{mL})$, THF $(2 \times 5 \mathrm{~mL})$ and $\mathrm{MeOH}(2 \times 5 \mathrm{~mL})$ and dried under high vacuum. The compound was cleaved from the support with $5 \mathrm{~mL}$ of a $10 \%$ solution of TFA in DCM for 50 minutes at room temperature. Then it was filtered and washed with $\mathrm{MeOH}$ $(2 \times 3 \mathrm{~mL})$ and $\mathrm{CH}_{2} \mathrm{Cl}_{2}(2 \times 3 \mathrm{~mL})$. The product-containing solution was concentrated under reduced pressure and dried under high vacuum. Esterification with diazomethane afforded the crude product that was analyzed by ${ }^{1} \mathrm{H}$ NMR and GC/MS and then purified by column chromatography (hexane/EtOAc).

Methyl 4'-((benzylamino)methyl)-[1,1'-biphenyl]-4-carboxylate (5af). Employing procedure E, with supported 3af. Column chromatography (90/10-hexane/EtOAc) provided the desired product in $63 \%$ overall isolated yield (five reactions steps) as white crystals.

Characterization of 5af. ${ }^{1} \mathrm{H}$ NMR $\left(\mathrm{CDCl}_{3}, 300 \mathrm{MHz}\right) \delta(\mathrm{ppm})$ : 3.85 (s, 2H), 3.87 (s, 2H), $3.94(\mathrm{~s}, 3 \mathrm{H}), 7.27-7.37(\mathrm{~m}, 5 \mathrm{H}), 7.52-$ $7.60(\mathrm{~m}, 3 \mathrm{H}), 7.45(\mathrm{~d}, J=8.3 \mathrm{~Hz}, 2 \mathrm{H}), 7.59(\mathrm{~d}, J=8.2 \mathrm{~Hz}, 2 \mathrm{H})$, $7.66(\mathrm{~d}, J=8.3 \mathrm{~Hz}, 2 \mathrm{H}), 8.10(\mathrm{~d}, J=8.3 \mathrm{~Hz}, 2 \mathrm{H}) ;{ }^{13} \mathrm{C} \mathrm{NMR}\left(\mathrm{CDCl}_{3}\right.$, $75 \mathrm{MHz}) \delta(\mathrm{ppm}): 52.1,52.7,53.2,126.9,127.0,127.3,128.2$, 128.5, 128.8, 130.1, 138.7, 140.1, 140.4, 145.4, 167.0. HRMS (ESI) $m / z 332.1659\left[\left(\mathrm{M}+\mathrm{H}^{+}\right)\right.$; calcd for $\mathrm{C}_{22} \mathrm{H}_{22} \mathrm{NO}_{2}$ : 332.1645].

\section{Procedure for the solid-phase synthesis of $\Delta^{2}$-isoxazoline (procedure F)}

$0.24 \mathrm{~g}$ of the supported 3 af $\left(0.736 \mathrm{mmol} \mathrm{g}^{-1}, 0.178 \mathrm{mmol}\right)$ was suspended in a mixture of anhydrous MeOH $(1 \mathrm{~mL})$ and DCM $(1 \mathrm{~mL})$ in a dram vessel. Anhydrous triethylamine $(124 \mu \mathrm{L}, 0.89$ $\mathrm{mmol}$ ) and hydroxylamine hydrochloride (62 $\mathrm{mg}, 0.89 \mathrm{mmol}$ ) were added and the reaction was stirred $36 \mathrm{~h}$ at room temperature. After that time, the oxime-resin was filtered, washed with DMF $(2 \times 5 \mathrm{~mL}), \operatorname{DCM}(2 \times 5 \mathrm{~mL}), \mathrm{MeOH}(2 \times 5$ $\mathrm{mL})$ and DCM $(2 \times 5 \mathrm{~mL})$ and dried under high vacuum. This oxime-resin was suspended in THF and treated with bleach (6 $\mathrm{mL}, 0.0018 \mathrm{mmol})$ and acrylic acid $(62 \mu \mathrm{L}, 0.9 \mathrm{mmol})$ at room temperature for 4 hours. The resin was washed with $\mathrm{MeOH}(2$ $\times 5 \mathrm{~mL}), \mathrm{H}_{2} \mathrm{O}(2 \times 5 \mathrm{~mL}), \mathrm{MeOH}(2 \times 5 \mathrm{~mL})$ and DCM $(2 \times 5$ $\mathrm{mL}$ ) and dried under high vacuum. The compound was cleaved from the support with $5 \mathrm{~mL}$ of a $20 \%$ solution of TFA in DCM for 50 minutes at room temperature. Then it was filtered and washed with $\mathrm{MeOH}(2 \times 3 \mathrm{~mL})$ and $\mathrm{CH}_{2} \mathrm{Cl}_{2}(2 \times 3 \mathrm{~mL})$. The 
product-containing solution was concentrated under reduced pressure and dried under high vacuum. Methylation with diazomethane afforded the crude product that was analyzed by ${ }^{1} \mathrm{H}$ NMR and GC/MS and then purified by column chromatography (hexane/EtOAc).

Methyl 3-(4'-(methoxycarbonyl)-[1,1'-biphenyl]-4-yl)-4,5dihydroisoxazole-5-carboxylate (7af). Employing procedure F, with supported 3af. Column chromatography (92/8 hexane/EtOAc) provided the desired compound in $21 \%$ overall isolated yield (five reactions steps), as white crystals.

Characterization of 7 af. ${ }^{1} \mathrm{H} \mathrm{NMR}\left(\mathrm{CDCl}_{3}, 300 \mathrm{MHz}\right) \delta(\mathrm{ppm})$ : $3.69(\mathrm{ABX}, J=17.1,11.5,9.5,5.2 \mathrm{~Hz}, 2 \mathrm{H}), 3.84(\mathrm{~s}, 3 \mathrm{H}), 3.95(\mathrm{~s}$, $3 \mathrm{H}), 5.23(\mathrm{dd}, J=10.7,7.4 \mathrm{~Hz}, 1 \mathrm{H}), 7.67(\mathrm{~d}, J=8.3 \mathrm{~Hz}, 4 \mathrm{H})$, $7.78(\mathrm{~d}, J=8.6 \mathrm{~Hz}, 2 \mathrm{H}), 8.12(\mathrm{~d}, J=8.3 \mathrm{~Hz}, 2 \mathrm{H}) .{ }^{13} \mathrm{C} \mathrm{NMR}$ $\left(\mathrm{CDCl}_{3}, 75 \mathrm{MHz}\right) \delta(\mathrm{ppm}): 38.8,52.2,52.9,78.1,127.0,127.5$, 127.6, 128.2, 129.5, 130.2, 142.0, 144.4, 155.7, 166.8, 170.7. HRMS (ESI) $m / z 362,0998\left[\left(\mathrm{M}+\mathrm{Na}^{+}\right)\right.$; calcd for $\mathrm{C}_{19} \mathrm{H}_{17} \mathrm{NNaO}_{5}$ : 362, 0999].

\section{Procedure for the solid-phase synthesis of imidazole (procedure G)}

$0.13 \mathrm{~g}$ of the supported $3 \mathrm{af}\left(0.736 \mathrm{mmol} \mathrm{g}^{-1}, 0.097 \mathrm{mmol}\right)$ was suspended in Glacial AcOH in a dram vessel. Benzylamine (212 $\mu \mathrm{L}, 1.94 \mathrm{mmol}$ ), benzil (408 $\mathrm{mg}, 1.94 \mathrm{mmol}$ ) and ammonium acetate $(9 \mu \mathrm{L}, 0.136 \mathrm{mmol})$ were added and the reaction was stirred $4 \mathrm{~h}$ at $100{ }^{\circ} \mathrm{C}$. After that time, the resin was filtered, washed $\mathrm{MeOH}(2 \times 5 \mathrm{~mL}), \mathrm{H}_{2} \mathrm{O}(2 \times 5 \mathrm{~mL})$, $\mathrm{MeOH}(2 \times 5 \mathrm{~mL})$ and DCM $(2 \times 5 \mathrm{~mL})$ and dried under high vacuum. The compound was cleaved from the support with 5 $\mathrm{mL}$ of a $20 \%$ solution of TFA in DCM for 50 minutes at room temperature. Then it was filtered and washed with $\mathrm{MeOH}(2$ $\times 3 \mathrm{~mL})$ and $\mathrm{CH}_{2} \mathrm{Cl}_{2}(2 \times 3 \mathrm{~mL})$. The product-containing solution was concentrated under reduced pressure and dried under high vacuum. Methylation with diazomethane afforded the crude product that was analyzed by ${ }^{1} \mathrm{H}$ NMR and then purified by column chromatography (hexane/ EtOAc).

Methyl 4'-(1-benzyl-4,5-diphenyl-1H-imidazol-2-yl)-[1,1'biphenyl]-4-carboxylate (9af). Employing procedure G, with supported 3af. Column chromatography (96/4 hexane/EtOAc) provided the desired compound in $20 \%$ overall isolated yield (four reactions steps), as yellow crystals.

Characterization of 9af. ${ }^{1} \mathrm{H}$ NMR $\left(\mathrm{CDCl}_{3}, 300 \mathrm{MHz}\right) \delta(\mathrm{ppm})$ : $3.94(\mathrm{~s}, 3 \mathrm{H}), 5.16(\mathrm{~s}, 3 \mathrm{H}), 6.86(\mathrm{~m}, 2 \mathrm{H}), 7.20(\mathrm{~m}, 8 \mathrm{H}), 7.32(\mathrm{~m}$, $3 \mathrm{H}), 7.59(\mathrm{~m}, 2 \mathrm{H}), 7.67(\mathrm{~m}, 4 \mathrm{H}), 7.77(\mathrm{~d}, J=8.4 \mathrm{~Hz}, 2 \mathrm{H}), 8.11(\mathrm{~d}, J$ $=8.0 \mathrm{~Hz}, 2 \mathrm{H}) .{ }^{13} \mathrm{C} \mathrm{NMR}\left(\mathrm{CDCl}_{3}, 75 \mathrm{MHz}\right) \delta(\mathrm{ppm}): 48.4,52.2$, 125.9, 126.5, 126.8, 127.0, 127.6, 128.1, 128.7, 128.8, 129.2, $129.5,130.2,130.4,130.6,130.9,131.0,134.3,137.5,138.3$, 140.3, 144.8, 147.5, 166.9. HRMS (ESI) $m / z$ 521, $2222\left[\left(\mathrm{M}+\mathrm{H}^{+}\right)\right.$; calcd for $\mathrm{C}_{36} \mathrm{H}_{29} \mathrm{~N}_{2} \mathrm{O}_{2}$ : 521, 2223].

\section{Acknowledgements}

Support from CONICET, ANPCyT and Universidad Nacional de Rosario from Argentina is gratefully acknowledged. MMA thanks CONICET for fellowship.

\section{Notes and references}

1 (a) T. E. Nielsen and S. L. Schreiber, Angew. Chem., Int. Ed., 2008, 47, 48; (b) C. J. O'Connor, L. Laraia and D. R. Spring, Chem. Soc. Rev., 2011, 40, 4332.

2 (a) W. R. J. D. Galloway, A. Isidro-Llobet and D. R. Spring, Nat. Commun., 2010, 1, 80; (b) H. Beckmann, C. J. O'Connor and D. R. Spring, Chem. Soc. Rev., 2012, 41, 4444.

3 E. Schütznerová, P. Verdía and V. Krchnak, ACS Comb. Sci., 2016, 18, 655.

4 D. D. Young and A. Deiters, Solid-phase organic synthesis: concepts, strategies, and applications, ed. P. H. Toy and Y. Lam, John Wiley \& Sons, Inc., Hoboken, New Jersey, 2012, pp. 171-201.

5 G. S. Yellol and C.-M. Sun, Solid-Supported Synthesis en Green Techniques for Organic Synthesis and Medicinal Chemistry, ed. W. Zhang and B. W. Cue Jr, John Wiley \& Sons, Ltd, 2012, p. 394.

6 N. Miyaura and A. Suzuki, Chem. Rev., 1995, 95, 2457.

7 For articles related to the suppression of the oxidative homocoupling, see: (a) W. D. Miller, A. H. Fray, J. T. Quatroche and C. D. Sturgill, Org. Process Res. Dev., 2007, 11, 359; (b) N. Miyaura, Metal-Catalyzed CrossCoupling Reaction, ed. F. Diederich and A. de Meijere, Wiley-VCH, New York, 2004, p. 41; (c) A. J. J. Lennox and G. C. Lloyd-Jones, Isr. J. Chem., 2010, 50, 664; (d) A. J. J. Lennox and G. C. Lloyd-Jones, J. Am. Chem. Soc., 2012, 134, 7431; (e) A. J. J. Lennox and G. C. Lloyd-Jones, Angew. Chem., Int. Ed., 2013, 52, 7362; (f) A. J. J. Lennox and G. C. Lloyd-Jones, Chem. Soc. Rev., 2014, 43, 412.

8 (a) S. Bräse, J. H. Kirchhoff and J. Köbberling, Tetrahedron, 2003, 59, 885; (b) N. Ljungdahl, K. Bromfield and N. Kann, Top. Curr. Chem., 2007, 278, 89; (c) S. A. Testero and E. G. Mata, J. Comb. Chem., 2008, 10, 487.

9 To the best of our knowledge, two examples have been reported dealing with the use of immobilized boronic acid in organic synthesis, in both cases, the sticky PEG-PS resin was the favorite support used: (a) B. Ruhland, A. Bombrun and M. A. Gallop, Tetrahedron Lett., 2006, 47, 19; (b) X. Li, A. K. Szardenings, C. P. Holmes, L. Wang, A. Bhandari, L. Shi, M. Navre, L. Jang and J. R. Grove, Tetrahedron Lett., 2006, 47, 19.

10 (a) S. A. Testero and E. G. Mata, Org. Lett., 2006, 8, 4783; (b) A. A. Poeylaut-Palena, S. A. Testero and E. G. Mata, J. Org. Chem., 2008, 73, 2024; (c) A. A. Poeylaut-Palena and E. G. Mata, J. Comb. Chem., 2009, 11, 791; (d) A. A. Poeylaut-Palena, S. A. Testero and E. G. Mata, Chem. Commun., 2011, 47, 1565; (e) A. La-Venia, S. A. Testero, M. Mischne and E. G. Mata, Org. Biomol. Chem., 2012, 10, 2514; (f) C. I. Traficante, C. M. L. Delpiccolo and E. G. Mata, ACS Comb. Sci., 2014, 16, 211; $(g)$ L. Méndez and E. G. Mata, ACS Comb. Sci., 2015, 17, 81; (h) C. I. Traficante, C. Fagúndez, G. L. Serra, E. G. Mata and C. M. L. Delpiccolo, ACS Comb. Sci., 2016, 18, 225. 
11 The large P-Pd-P angle of the dppf ligand is believed to make the reductive elimination of the coupling product much faster than the $\beta$-elimination. See: T. Hayashi, M. Konishi, Y. Kobori, M. Kumada, T. Higuchi and K. Hirotsu, J. Am. Chem. Soc., 1984, 106, 158.

12 M. Ruda, N. Kann, S. Gordon, J. Bergman, W. Nelson, P. Agback, L. Hagberg and K. F. Koehler, J. Comb. Chem., 2005, 7, 567.

13 V. Cerezo, M. Amblard, J. Martinez, P. Verdié, M. Planas and L. Feliu, Tetrahedron, 2008, 64, 10538.

14 A. A. Poeylaut-Palena and E. G. Mata, Org. Biomol. Chem., $2010,8,3947$.

15 C. O. Kappe and D. Dallinger, Mol. Diversity, 2009, 13, 71.

16 C. Amatore, G. Le Duc and A. Jutand, Chem.-Eur. J., 2013, 19, 10082.

17 Y. Liu, C. Khemtong and J. Hu, Chem. Commun., 2004, 398.

18 S. A. Testero, J. F. Fisher and S. Mobashery, $\beta$-Lactam Antibiotics in Burger's Medicinal Chemistry, Drug Discovery and Development, Vol. 7 (Antiinfectives), ed. D. J. Abraham and D. P. Rotella, Wiley and Sons, 2010, pp. 259-404.

19 D. A. Burnett, Curr. Med. Chem., 2004, 11, 1873.

20 E. Martinez, J. J. Talley, S. Antonelli, T. Barden, R. Lundrigan-Soucy, W. Schairer, J. J. Yang and D. Zimmer, 4-Biarylyl-1-phenylazetidin-2-ones, US Pat., 2005/0209165 A1, 22 September 2005.

21 E. Turos, C. Coates, J.-Y. Shim, Y. Wang, J. M. Leslie, T. E. Long, G. S. K. Reddy, A. Ortiz, M. Culbreath, S. Dickey, D. V. Lim, E. Alonso and J. Gonzalez, Bioorg. Med. Chem., 2005, 13, 6289.

22 D. Ashok, B. V. Lakshmi, S. Ravi, A. Ganesh and S. Adam, Chem. Heterocycl. Compd., 2015, 51, 462.

23 (a) W. Kemnitzer, S. Kashibhatla, S. Jiang, H. Zhang, J. Zhao, S. Jia, L. Xu, C. Crogan-Gundy, R. Denis, N. Rarriault, L. Vaillancourt, S. Charron, J. Dodd, G. Attardo, D. Labreque, S. Lamothe, H. Gourdeau, B. Tseng, J. Drewe and S. X. Cai, Bioorg. Med. Chem. Lett., 2005, 15, 4745; (b) S. Combes, P. Barbier, S. Douillard, A. McLeer-Florin, V. Bourgarel-Rey, J.-T. Pierson, A. Y. Fedorov, J.-P. Finet, J. Boutonnat and V. Peyrot, J. Med. Chem., 2011, 54, 3153.

24 M. L. Yao and M. Z. A. Deng, Chem. Heterocycl. Compd., 2000, 11, 380 .

25 S. Wattanasin, Synth. Commun., 1988, 18, 1919.
26 N. Zou and B. Jiang, J. Comb. Chem., 2000, 2, 6.

27 J. F. Cheng and A. M. Mjalli, Tetrahedron Lett., 1998, 39, 939.

28 A. Alam, C. Pal, M. Goyal, M. K. Kundu, R. Kumar, M. S. Iqbal, S. Dey, S. Bindu, S. Sarkar, U. Pal, N. C. Maiti, S. Adhikari and U. Bandyopadhyay, Bioorg. Med. Chem., 2011, 19, 7365.

29 B. S. Priya and K. S. Rangappa, Heterocycl. Commun., 2006, $12,35$.

30 S. L. Gaonkar, K. L. Rai and B. Prabhuswamy, Med. Chem. Res., 2007, 15, 407.

31 R. E. Sammelson, T. Ma, L. J. Galietta, A. S. Verkman and M. J. Kurth, Bioorg. Med. Chem. Lett., 2003, 13, 2509.

32 (a) Y. Al-Abed and S. VanPatten, Future Med. Chem., 2011, 3, 45; (b) Y. Al-Abed, D. Dabideen, B. Aljabari, A. Valster, D. Messmer, M. Ochani, M. Tanovic, K. Ochani, M. Bacher, F. Nicoletti, C. Metz, V. A. Pavlov, E. J. Miller and K. J. Tracey, J. Biol. Chem., 2005, 280, 36541.

33 For recent reviews on the biological activity of imidazoles, see: (a) M. M. Heravi, M. Daraie and V. Zadsirjan, Mol. Diversity, 2015, 19, 577; (b) N. Rani, A. Sharma and R. Singh, Mini-Rev. Med. Chem., 2013, 13, 1812; (c) A. Mumtaz, A. Saeed, N. Fatima, M. Dawood, H. Rafique and J. Iqbal, Bangladesh J Pharmacol, 2016, 11, 756.

34 (a) G. V. M. Sharma, Y. Jyothi and P. S. Lakshmi, Synth. Commun., 2006, 36, 2991; (b) S. Sarshar, D. Siev and A. M. Mjalli, Tetrahedron Lett., 1996, 37, 835.

35 F. Izquierdo, M. Corpet and S. P. Nolan, Eur. J. Org. Chem., 2015, 1920.

36 C. Liu, T. Li and N. L. Rosi, J. Am. Chem. Soc., 2012, 134, 18886.

37 Y. A. Chen and C. Y. Liu, RSC Adv., 2015, 5, 74180.

38 T. Cornilleau, P. Hermange and E. Fouquet, Chem. Commun., 2016, 52, 10040.

39 C. I. Traficante, E. G. Mata and C. M. L. Delpiccolo, $R S C A d v$, 2015, 5, 26796.

40 K. Kawabata, M. Takeguchi and H. Goto, Macromolecules, 2013, 46, 2078.

41 N. P. Cheval, A. Dikova, A. Blanc, J. M. Weibel and P. Pale, Chem.-Eur. J., 2013, 19, 8765.

42 C. Palomo, M. Oiarbide, A. Esnal, A. Landa, J. I. Miranda and A. Linden, J. Org. Chem., 1998, 63, 5838.

43 D. L. Boger and J. B. Myers Jr, J. Org. Chem., 1991, 56, 5385. 